\title{
Global Data Meets 3-D Printing: The Quest for a Balanced and Globally Collaborative Solution to Prevent Patent Infringement in the Foreseeable 3-D Printing Revolution
}

Tyler Macik

Indiana University Maurer School of Law, tymacik@indiana.edu

Follow this and additional works at: https://www.repository.law.indiana.edu/ijgls

Part of the Intellectual Property Law Commons, International Law Commons, and the Technology and Innovation Commons

\section{Recommended Citation}

Macik, Tyler (2015) "Global Data Meets 3-D Printing: The Quest for a Balanced and Globally Collaborative Solution to Prevent Patent Infringement in the Foreseeable 3-D Printing Revolution," Indiana Journal of Global Legal Studies: Vol. 22 : Iss. 1 , Article 9.

Available at: https://www.repository.law.indiana.edu/ijgls/vol22/iss1/9

This Note is brought to you for free and open access by the Law School Journals at Digital Repository @ Maurer Law. It has been accepted for inclusion in Indiana Journal of Global Legal Studies by an authorized editor of Digital Repository @ Maurer Law. For more information, please contact rvaughan@indiana.edu.

\section{$\Psi$}

JEROME HALL LAW LIBRARY

INDIANA UNIVERSITY

Maurer School of Law
Blooming ton 


\title{
Global Data Meets 3-D Printing: The Quest for a Balanced and Globally Collaborative Solution to Prevent Patent Infringement in the Foreseeable 3-D Printing Revolution
}

\author{
TYLER MACIK ${ }^{*}$
}

\begin{abstract}
This Note explores a potential global solution to the foreseeable patent infringement problems with 3-D printing and do-it-yourself users. More specifically, at a time when $3-D$ printing is quickly gaining popularity and recognition for its many beneficial applications through advancements in printing and scanning technology, the current state of patent law lacks the ability to detect and prevent patent infringement among do-it-yourself users of 3-D printing. I propose a potential global solution that would provide a balance between fostering growth in 3-D printing and upholding patentees' rights by exploring the possibility of creating a collaborative, intergovernmental 3-D CAD file database that utilizes 3-D CAD file recognition software that must be cross-referenced by 3-D printers as a prerequisite to printing any 3-D CAD file. The creation of this type of collaborative global database would yield benefits to inventors, countries' patent offices, and patentees, while ensuring 3-D printing continues to benefit direct and indirect users around the world. Ultimately, this proposal, along with the facts and issues presented in this note, helps to convey the importance of why a proactive solution to potential patent infringement issues accompanying quickly advancing 3D-printing technology should remain on patent attorneys', legislators', and patentees' radars.
\end{abstract}

* Managing Editor, Indiana Journal of Global Legal Studies, Volume 22; JD 2015, Indiana University Maurer School of Law; BS 2009, Purdue University. I would like to thank God for his blessings and guidance. I would also like to thank Professors Leandra Lederman and Michael Mattioli for their suggestions and advice, which made this Note possible. Further, I would like to thank my wife for her never-ending support and inspiration, as well as my family for instilling in me the work ethic and drive to push myself and learn in everything I do.

Indiana Journal of Global Legal Studies Vol. 22 \#1 (Winter 2015)

(c) Indiana University Maurer School of Law 


\section{INTRODUCTION}

The advent of additive manufacturing, better known as 3-D printing, has brought to reality what was once believed to have existed in only science fiction television shows such as Star Trek or The Jetsons: the ability "to print functional components from scratch." 1 Multiple compounds-including plastics, metals, and even food-are stacked in microscopic layers, ${ }^{2}$ creating physical objects like rocket engine components, ${ }^{3}$ iPhone cases, ${ }^{4}$ and even pizza ${ }^{5}$ in a matter of minutes. By utilizing design software that has been used for decades by architects, engineers, and designers, users can create, modify, or download computer-aided design (CAD) files and produce the physical version of their 3-D CAD files via 3-D printing. ${ }^{6}$

Many sources report that the applications of 3-D printing are limitless, with the potential to start a "third industrial revolution." The ability to print endless arrays of individualized, physical goods at the click of a button has sources pondering over the potential "deglobalization" of manufacturing, yielding the prospect of bypassing lowcost, foreign production and the accompanying maze of unpredictable, global logistics. ${ }^{8}$ The potential of 3-D printing has already begun

1. Jon Excell \& Stuart Nathan, The Rise of Additive Manufacturing, EnGINEER (May 24, 2010), http://www.theengineer.co.uk/in-depth/the-big-story/the-rise-of-additive-manufacturing/ 1002560.article.

2. See Ashlee Vance, 3-D Printing Spurs a Manufacturing Revolution, N.Y. TIMES (Sept. 13, 2010), http:/www.nytimes.com/2010/09/14/technology/14print.html?mabReward= relbias:r,\%7B\&\%2334 (describing the process of printing compounds in multiple layers).

3. Rachel Kraft et al., NASA Tests Limits of 3-D Printing with Powerful Rocket Engine Check, NASA (Aug. 27, 2013), http://www.nasa.gov/press/2013/august/nasa-testslimits-of-3-d-printing-with-powerful-rocket-engine-check/\#.UoUV4ZH70ir.

4. See Amy O'Leary, 3-D Printers to Make Things You Need or Like, N.Y. TIMES (June 19, 2013), http://www.nytimes.com/2013/06/20/technology/personaltech/home-3-d-printersto-make-things-you-need-or-just-like.html?pagewanted=all\&module $=\mathrm{S} \% \mathrm{E} 2 \% 80 \% \mathrm{~A} 6 \& \_\mathrm{r}=0$ (explaining the ability to print multiple objects, including iPhone cases).

5. See Michelle Starr, NASA-Funded 3D Pizza Printer Debuts at SXSW Eco, CNET (Oct. 11, 2013, 5:06 PM), http://www.cnet.com.au/nasa-funded-3d-pizza-printer-debuts-atsxsw-eco-339345631.htm (detailing the ability to 3-D print food from food powder that can be sustained for years).

6. See Michael Weinberg, Pub. Knowledge, it Will Be Awesome if They Don't ScRew It UP: 3D Printing, InTEllectual Property, aNd the Fight Over the NeXT GREAT DISRUPTIVE TECHNOLOGY 2-3 (2010), http://publicknowledge.org/files/docs/ 3DPrintingPaperPublicKnowledge.pdf (referencing the use of CAD files to create 3-D printed objects).

7. A Third Industrial Revolution, ECONOMIST (Apr. 21, 2012), available at http://www.economist.com/node/21552901.

8. Baizhu Chen, Yes, We Can Make iPhones in America, Forbes (Sept. 7, 2012, 9:02 PM), http.i'www.forbes.com/sites/baizhuchen/2012/09/07/yes-we-canmake-iphones-in-america/; see Betty Ng, Globalization vs. Localization - Time to Rethink the Economics of Emerging 
catching the attention of investors, such as banking giant Morgan Stanley, which expects the global 3-D printing market to grow at an annual rate of 20 percent, from a current market totaling $\$ 2$ billion, to a $\$ 9$ billion market within the next seven years. ${ }^{9}$

Indeed, the array of possibilities for 3-D printing is exciting, but the potential patent infringement issues raised by these possibilities have been hardly publicized, except within legal and 3-D printing circles. These patent infringement issues especially pertain to the "do-ityourself" (DIY) community, which is keen on the "creation, modification, or repair of objects without the aid of paid professionals." 10 The DIY community causes the greatest concern when it comes to potential patent infringement, especially given the recent global availability and increased popularity of professional quality 3-D scanners, ${ }^{11}$ 3-D printers, ${ }^{12}$ and easy access to $3-\mathrm{D}$ CAD file-sharing communities. ${ }^{13}$ It is unlikely that a DIY producer of a 3-D printed object will be caught unless the infringing product is publicized or commercially produced because the production of the infringing product can easily go undetected. Even if known, the potential cost of a lawsuit is likely to deter the patent holder from suing when compared to the relatively minimal potential damages from a single infringer. ${ }^{14}$ Pursuing DIY

Markets, WORLDCRUNCH (Mar. 12, 2012), http://www.worldcrunch.com/china-2.0/ globalization-vs.-localization-time-to-rethink-the-economics-of-emerging-markets/chinaeconomy-offshore-manufacturing-production/c9s11082/ (describing the localization of manufacturing back to Western economies).

9. See Morgan Stanley Research, Capital Goods: 3D Printing - Don't Believe (ALL) THE HYPE 20 (2013).

10. Stacey Kuznetsov \& Eric Paulos, Rise of the Expert Amateur: DIY Projects, Communities, and Cultures, 6 NORDIC CONF. ON HUMAN-COMPUTER INTERACTION 295, 295 (2010), available at http://www.staceyk.org/hci/KuznetsovDIY.pdf.

11. See Jason Dorrier, $3 D$ iPad Scanner by Occipital Digitizes the World for $3 D$ Printing and Augmented Reality, SINGULARITY HUB (Sept. 23, 2013), http://singularityhub.com/2013/09/23/3d-ipad-scanner-by-occipital-digitizes-the-world-for3d-printing-and-augmented-reality/ (exhibiting the capabilities of a 3-D scanner that clips onto Apple's iPad); MAKERBOT, http://store.makerbot.com/digitizer.html (last visited Nov. 14, 2013) (explaining the "two-click simplicity" of using MakerBot's 3-D scanner); NEXTENGINE, http://www.nextengine.com (last visited Nov. 14, 2013) (displaying bestselling 3-D scanner used in over ninety countries).

12. See O'Leary, supra note 4 (describing consumer models ranging from $\$ 300$ to $\$ 4,000$, and how Amazon.com is now selling 3-D printers).

13. See MAKerBotTHINGIVERSE, http://www.thingiverse.com/about (last visited Nov. 14, 2013) (encouraging discovering, making, and sharing of 3-D printable models); Angela Moscaritolo, Defcad, the 'Pirate Bay' of $3 D$ Printing, Seeks Funding, PC MaG. (Mar. 13, 2013, 2:50 PM), http://www.pcmag.com/article2/0,2817,2416559,00.asp (explaining how DEFCAD has become "The Pirate Bay of 3D printing" and offers "unfettered access" to 3-D printable designs).

14. See Eric Michael, Patents 101: Does DIY Infringe?, GLASSBox Design (Feb. 27, 2009), http://glassbox-design.com/2009/patents-101-does-diy-infringe/ (explaining how 
users abroad would be even more daunting, given the increased cost of international litigation. This inability to prevent DIY producers from infringing on patents, especially in remote locations throughout the world, combined with the predicted global growth in the 3-D printing industry as technology advances, raises concern about the potential aggregate effect 3-D printing can have on businesses and innovations that depend on patents.

Such concerns have already begun spurring potential solutions within legal and 3-D printing circles. ${ }^{15}$ These proposals have ranged from an outright ban on 3-D scanning ${ }^{16}$ to pursuing CAD file hosting websites under a theory of contributory patent infringement. ${ }^{17}$ Very few proposed solutions have managed to strike a balance between allowing the 3-D printing industry to grow while protecting patent owners' rights, and none of these confront the potential global, aggregate effect and ability of the DIY community to unknowingly or carelessly infringe on patents. ${ }^{18}$

The purpose of this Note is to explore a potential global solution to this foreseeable problem, while allowing the public to continue garnering the benefits yielded by the rapidly growing, beneficial, and exciting industry of 3-D printing. A potential global solution that would

although a DTY 3-D printer can infringe, a patentee is unlikely to bring suit); E. Robert Yoches et al., Securing IP Rights in a 3D-Printing World, FINNEGAN (Dec. 18, 2013), $\mathrm{http} / / / \mathrm{www}$.finnegan.com/resources/articles/articlesdetail.aspx?news $=\mathrm{d} 262620 \mathrm{e}-11 \mathrm{~d} 2$ -

4033-9b5b-6b29bb1345d6 (expounding on how suing an individual infringer through the courts may not be cost-effective). See generally Davis Doherty, Note, Downloading Infringement: Patent Law as a Roadblock to the 3D Printing Revolution, 26 HARV. J.L. \& TECH. 353, 354 (2012) (explaining the difficulties in discovering an infringing DIY producer).

15. See generally Doherty, supra note 14, at 354-72 (proposing multiple, proactive solutions to potential patent infringement by 3-D printers); Brian Rideout, Printing the Impossible Triangle: The Copyright Implications of Three-Dimensional Printing, 5 PEPP. J. BUS. ENTREPRENEURSHIP \& L. 161, 173-75 (2011) (proposing multiple solutions to patent and copyright infringement via 3-D printers); Peter Hanna, The Next Napster? Copyright Questions as $3 D$ Printing Comes of Age, ARS TeChNICA (Apr. 6, 2011, 12:35 AM), http://arstechnica.com/tech-policy/2011/04/the-next-napster-copyright-questions-as-3d-

printing-comes-of-age/3/ (discussing lawmakers potentially forbidding making 3-D models from scans).

16. See Hanna, supra note 15 , at 3.

17. See 35 U.S.C. $\S 271$ (c) (2006); Rideout, supra note 15, at 173-74 (discussing the potential pursuance of $\mathrm{CAD}$ file hosting websites under contributory patent infringement). See generally Deven R. Desai \& Gerard N. Magliocca, Patents, Meet Napster: 3D Printing and the Digitization of Things, 102 GEO. L.J. 1691 (2014) (mentioning how CAD file hosting websites could be sued for contributory infringement).

18. See, e.g., Doherty, supra note 14, at 365-69 (proposing a "Digital Millennium Patent Act" reminiscent of the "Digital Millennium Copyright Act," while allowing an "innocent independent inventor" defense). 
provide a balance between growth in 3-D printing and upholding patentees' rights can be found through the means of creating a collaborative, intergovernmental 3-D CAD file database that utilizes 3 $\mathrm{D}$ CAD file recognition software that must be cross-referenced by 3-D printers as a prerequisite to printing any 3-D CAD file. A collaborative global database of this type would benefit inventors, countries' patent offices, and patentees, all while ensuring that the growth of 3-D printing continues to benefit direct and indirect users around the world. These users span individuals desiring the newest pair of designer sunglasses to those in need of medical devices in remote or disaster-stricken areas. ${ }^{19}$

Part I of this Note provides insight into 3-D printing, where the 3-D printing industry is moving, and the ease of infringement within the DIY community. Part II of this Note discusses the application of existing intellectual property (IP) laws to proposed solutions attempting to prevent the foreseeable and pervasive potential of patent infringement with 3-D printing. Part III explores the possibility of a collaborative, intergovernmental 3-D CAD file database that requires pre-printing, cross-referencing of 3-D CAD files through hypothetical 3-D CAD file recognition software before a 3-D printer can print any object. The Note concludes by discussing the importance of coming to a proactive solution that allows and enforces valuable IP rights while allowing innovation to flourish within the $3-\mathrm{D}$ printing industry.

\section{The Potential Infringement Issues RAISED BY 3-D PRINTING}

3-D printing, or additive manufacturing, has been used since the 1980s, when it first appeared in professions like architecture and engineering. ${ }^{20}$ At the time, its use was predominantly limited to these types of businesses due to the high cost of a 3-D printer (around $\$ 100,000$ ) and because these professions were familiar with complex CAD file and design software programs. ${ }^{21}$ The use of these software

19. See Jason Koebler, Is $3 D$ Printing the Future of Disaster Relief?, MOTHERBOARD (Oct. 25, 2013, 10:20 AM), http://motherboard.vice.com/blog/is-3d-printing-the-future-ofdisaster-relief (describing the potential uses of 3-D printing for disaster relief, as 3-D printed umbilical cord clamps are already being used in Haiti); cf. Desai \& Magliocca, supra note 17, at 1705 (stating how firms would be better off not lobbying for legal limits on 3-D printing technology, but rather "embracing this change in production to cultivate new markets.").

20. See Doherty, supra note 14, at 356 (citing U.S. Patent No. 4,575,330, filed Aug. 8, 1984, patenting the stereolithography process); see also WEINBERG, supra note 6 , at 3 (referencing professions originally using 3-D printing).

21. See Tony Hoffman, 3D Printing: What You Need to Know, PC MaG. (Oct. 17, 2011), http://www.pcmag.com/article2/0,2817,2394722,00.asp (describing the price of 3-D printers 
programs is required to create 3-D CAD files that are uploaded to 3-D printers, which then cut "the virtual object in $2 \mathrm{D}$ slices and print] the real object slice by slice. . . [whereby the] [s]lices are printed on top of each other . . gain[ing] volume every time a slice is added." 22

The 3-D printing world has changed in three important ways since the $1980 \mathrm{~s}$. First, it is now possible to print in multiple materials, including titanium, ${ }^{23}$ gold, ${ }^{24}$ and even food, ${ }^{25}$ most of which can be rendered from powder printing cartridges. The results of printing in multiple materials yield endless possibilities, as $3-\mathrm{D}$ printers are currently being used in numerous industries, with some of the more impressive advances being made in aerospace, ${ }^{26}$ food, ${ }^{27}$ and medical applications. ${ }^{28}$ Second, 3-D printers also have the ability to print multiple colors based on the uploaded 3-D CAD files. ${ }^{29}$ Third, 3-D printing is now accessible for the mainstream consumer, facilitated by cheaper machinery; online 3-D CAD file sharing and help communities;

being approximately $\$ 100,000$ in the 1980 s). See generally HoD LIPSON \& MELBA KURMAN, FACTORY @ Home: The EMERging Economy of Personal MANUFACTuRing 3 (2010), available at https:/www.ida.org/ /media/Corporate/OccasionalPapers/OP-5-2010-Personal Fabrication-v3.ashx (describing the adoption of at-home manufacturing through 3-D printers, thanks in part to the "easier-to-use computer aided design (CAD) software").

22. 3D Printing Process, CREATE IT REAL, http://www.createitreal.com/index.php/ technology/process (last visited Nov. 19, 2013).

23. See Paul Ridden, World's First 3D-Printed Lower Jaw Implant Gives 83-Year Old Patient Her Bite Back, GIZMAG (Feb. 8, 2012), http://www.gizmag.com/first-3d-printedlower-jaw-implant/21383/ (referencing the ability to print a titanium lower jaw); Martin LaMonica, 3D Printer Produces New Jaw for Woman, CNET (Feb. 6, 2012, 12:59 PM), http://news.cnet.com/8301-11386_3-57372095-76/3d-printer-produces-new-jaw-for-woman/.

24. See Additive Manufacturing in Gold, Hoptroff London: The TIMe Diaries (July 29, 2013), http:/www.hoptroff.com/blogs/news/8387420-additive-manufacturing-in-gold (explaining the technique and results of 3-D printing in gold); Martin Larsson, What Materials Does a $3 D$ Printer Use?, INKPAL.COM (Mar. 11, 2013), http://www.inkpal.com/ ink-news/what-materials-does-a-3d-printer-use/ (referencing the ability to $3 D$ print in gold from powdered gold).

25. See Starr, supra note 5.

26. See Kraft et al., supra note 3 (describing the use of 3-D printing in functional rocket engine components); NASA Plans First $3 D$ Printer Space Launch in 2014, BBC NEwS (Sept. 30, 2013), http:/www.bbc.co.uk/news/technology-24329296 (discussing how NASA is planning on sending 3-D printers into space on missions to produce spare parts and tools).

27. See A.J. Jacobs, Op-Ed., Dinner is Printed, N.Y. TIMES (Sept. 22, 2013), http://www.nytimes.com/2013/09/22/opinion/sunday/dinner-is-printed.html?_r=0 (describing the experience of eating an entire meal printed by a 3-D printer); Starr, supra note 5.

28. See Thomas Ehrlich \& Ernestine Fu, Our Future With 3D Printers: 7 Disrupted Industries, ForBES (Oct. 29, 2013, 1:32 PM), http://www.forbes.com/sites/ehrlichfu/2013/ 10/29/our-future-with-3-d-printers-7-disrupted-industries/ (describing how simple softtissues, such as an ear, finger, or kidney can now be produced via 3-D printing); Ridden, supra note 23.

29. See 3D SYSTEMS, INC., http://cubify.com/cubex/ (last visited Nov. 20, 2013) (displaying the ability to 3-D print in multi-color). 
simpler $\mathrm{CAD}$ file software; and the availability of input materials to print. ${ }^{30}$ 3-D printing's expansion can be exemplified by a simple search on Amazon.com, as one can find, purchase, and ship a variety of 3-D printers ranging in cost from $\$ 300$ to $\$ 3,999 .{ }^{31}$

Technology has also spurred advances made in $3-\mathrm{D}$ scanning. It is now possible for "[a]nybody with the right software and machine [to] 3D scan an existing product or download a proprietary blueprint and make as many copies of copyrighted and patented physical objects as they desire." 32 The ability to produce high-quality, 3-D scanned images of physical objects at home is even being promoted by celebrities. ${ }^{33} 3-\mathrm{D}$ scanners may fit within the confines of a desktop, ${ }^{34}$ scan in highdefinition, ${ }^{35}$ and yield dimensional accuracy within 2 millimeters. ${ }^{36}$ Additionally, some 3-D scanners have the ability to immediately upload your scanned object from the 3-D CAD software directly to the Internet, including social media websites. ${ }^{37}$

The capabilities of 3-D printers and 3-D scanners will likely continue to improve and decrease in price. ${ }^{38}$ With the ease of use of 3-D scanners and 3-D printers, combined with society's growing familiarity with and access to technology, one cannot help but ponder the potential for intellectual property infringement issues that this amazing technology raises. The facts speak for themselves when it comes to the current advancement of more accurate, smaller-scale, and affordable 3$\mathrm{D}$ scanners and printers. Although some have downplayed the potential

30. See generally LIPSON \& KURMAN, supra note 21 , at 9 (discussing the facilitation of mainstream 3-D printing).

31. See O'Leary, supra note 4 (describing 3-D printers starting at $\$ 300$ on Amazon.com); Industrial \& Scientific: "3D printer", AMAZON.COM, http:/www.amazon.com/ $\mathrm{s} / \mathrm{ref}=\mathrm{sr} \_s t$ ?keywords $=3 \mathrm{D}+$ printer\&qid $=1385048440 \& \mathrm{rh}=\mathrm{n} \% 3 \mathrm{~A} 16310091 \% 2 \mathrm{Ck} \% 3 \mathrm{~A} 3 \mathrm{D}+$

printer\&sort=-price (last visited Nov. 21, 2013) (displaying a simple product search of 3-D printers on Amazon.com).

32. LIPSON \& KURMAN, supra note 21 , at 79.

33. See NEXTENGINE, supra note 11 (showing Jay Leno promoting the capabilities of the World's most popular 3-D scanner).

34. See id. (displaying the small size of the NextEngine 3D scanner); MAKERBoT, supra note 11 (displaying the small size of the MakerBot 3-D scanner).

35. See NEXTENGINE, http://www.nextengine.com/products/hd-technology (last visited Nov. 21, 2013) (describing the ability to scan in high-definition).

36. See MAKERBoT, supra note 11 (describing a dimensional accuracy of $+/-2$ millimeters); NEXTENGINE, supra note 38 (describing dimensional accuracy of 0.002 inches).

37. See MAKERBOT, supra note 11 (describing the ability to immediately upload a 3-D scanned object to the Internet, subsequent to scanning).

38. See Richard A. D'Aveni, 3-D Printing Will Change the World, HARV. Bus. REv., Mar. 2013, at 34 (discussing the possibilities of $3-D$ printing while applications of the technology expand and prices fall). 
need to worry about accurate, smaller-scale, ${ }^{39}$ and affordable 3-D scanning and printing ${ }^{40}$ from DIY users, ${ }^{41}$ intellectual property owners remain cautious.

Sharing and downloading illegal or infringing objects from 3-D CAD files shared throughout the 3-D printing community is currently possible and will likely increase. ${ }^{42}$ For example, the U.S. State Department ordered DEFCAD to remove the 3-D CAD file for a 3-D printable gun, but other websites, such as The Pirate Bay, continued to defiantly host this 3-D CAD file for download. ${ }^{43}$ The ability of DIY users to access, share, and download high-quality 3-D CAD files via filesharing websites raises concerns among intellectual property owners about the potential for widespread infringement issues. With the foreseeable widespread use of 3-D printers in everyday lives, patent owners should fear the DIY users who, either carelessly or unwittingly, independently create or download infringing designs with 3-D printers. ${ }^{44}$

\section{The Minimal Protections From DIY Users of EXISTING PATENT LAW}

Multiple avenues of current patent law can be pursued when attempting to protect and enforce patent rights to prevent patent infringement in the 3-D printing industry, but what Daniel Brean has

39. See Dorrier, supra note 11 (explaining the capabilities of a small-scale 3-D scanner that attaches to and runs on an iPad and costs \$349); MAKERBOT, supra note 11 (displaying high-resolution 3-D scanning capabilities of a desktop 3-D scanner "optimized for 3D printing").

40. See David Lumb, Finally, An Affordable 3-D Printer Big Enough to Print More Than Trinkets, FAST COMPANY (Aug. 29, 2013), http://www.fastcolabs.com/3016615/finallyan-affordable-3-d-printer-big-enough-to-print-more-than-trinkets (displaying a 3-D printer that is larger and more precise when printing layers than competing DIY printers, shipped and assembled for $\$ 1295$ ); O'Leary, supra note 4 (describing 3-D printers starting at $\$ 300)$.

41. Charles W. Finocchiaro, Note, Personal Factory or Catalyst for Piracy? The Hype, Hysteria, and Hard Realities of Consumer 3-D Printing, 31 CARDOZO ARTS \& ENT. L.J. 473,491 (2013) (stating the difficulties with infringement by translating a protected object into a physical recreation by $3-\mathrm{D}$ scanning and printing).

42. See, e.g., Evolution: New Category, THE PIRATE BAY (Jan. 23, 2012), http://thepiratebay.se/blog/203 (describing one of the most notorious illegal file sharing websites' next endeavor into the world of CAD file sharing for use with 3-D printers and scanners); Moscaritolo, supra note 13 (describing one group's plan for a website aimed at providing "unfettered access to 3D printable firearms" and other 3-D printable parts).

43. Ian Steadman, US Government Seizes 3D-Printed Gun Files, but Still Shared Elsewhere, WIRED.CO.UK (May 10, 2013), http://www.wired.co.uk/news/archive/201305/10/defcad-gun-design-taken-down.

44. Doherty, supra note 14 , at 359. 
suggested as the most efficient means to enforcing patent rights, ${ }^{45}$ under a theory of indirect infringement, ${ }^{46}$ seems unlikely under current patent law. Even though it would be simple to show that a DIY user who 3-D prints a patented object is directly infringing a patent, ${ }^{47}$ attempting to pursue every DIY user who prints a patented product would be very costly and thus inefficient. ${ }^{48}$ Under the theory of indirect infringement, a patentee would seek damages from websites hosting 3-D $\mathrm{CAD}$ files, which, if printed, would infringe the respective patent. ${ }^{49}$ Even a "Digital Millennium Patent Act" has been proposed, reminiscent of the "Digital Millennium Copyright Act" (DMCA), as the best solution to finding a fine balance between fostering innovation and growth in the 3 -D printing industry, while protecting intellectual property owners. ${ }^{50}$

Although using the indirect infringement theory may currently be the most efficient means of enforcing intellectual property rights within the 3-D printing industry, it is ineffective in a critical way. Indirect infringement does not address the aggregate effect that the inevitable, ubiquitous community of DIY users may have on intellectual property rights. This will be the case if the DIY community fails to acknowledge intellectual property rights while having unfettered access to 3-D CAD files through 3-D scanners and defiant websites, such as The Pirate Bay or DEFCAD. ${ }^{51}$ These potential problems seem reminiscent of the

45. See Daniel Harris Brean, Asserting Patents to Combat Infringement via $3 D$ Printing: It's No 'Use", 23 FORDHAM INTELL. PROP. MEDIA \& ENT. L.J. 771, 789 (2013) (proposing it would be more efficient to pursue a theory of infringement that finds distributors of CAD files liable rather than individuals or DIY users).

46. See 35 U.S.C. $\S 271(b)-(c)$ (2006).

47. See 35 U.S.C. $§ 271$ (a) (2006) (referring to direct patent infringement as the "making" of a patented product).

48. See Brean, supra note 45 , at 804 (describing the pursuit of every 3-D printer of a patented object as being "highly inefficient").

49. See generally Rideout, supra note 15 (explaining the possibility of hosting websites infringing based on indirect patent infringement).

50. See Doherty, supra note 14, at 364-70 (proposing the "Digital Millennium Patent Act" and allowing a "safe harbor" rule for "innocent independent inventors" that unknowingly print a patented object); see also Desai \& Magliocca, supra note 17, at 171314 (proposing the enactment of a Digital Millennium Patent Act "that would impose notice and takedown rules on the sites that host 3D printing software"); Trademark, Patent, or Copyright?, USPTO, http://www.uspto.gov/trademarks/basics/definitions.jsp (last updated Jan. 18, 2013) (describing a patent as "a limited duration property right relating to an invention, granted by the United States Patent and Trademark Office in exchange for public disclosure of the invention," and a copyright as protecting "works of authorship, such as writings, music, and works of art that have been tangibly expressed").

51. See generally Moscaritolo, supra note 13 (explaining how DEFCAD has become the new illegal file sharing site); Yoches et al., supra note 14 (expounding on the difficulty in enforcing IP rights when individuals have at home scanners and peer-to-peer file sharing networks). 
problems seen with sharing music; yet they are different, as effective remedies-such as the DMCA - and case law on the subject do not yet exist. "This state of the law leaves patentees virtually helpless to combat a large class of infringement of their product claims." 52

Even if offending 3-D CAD file hosting websites were taken down under indirect patent infringement, who is to say that other-perhaps many more-websites would not take it upon themselves to begin distributing the same infringing 3-D CAD files? Frustration, anger, and a mixed array of emotions may ensue among the DIY community from the takedown of the worst offending websites, thus causing an exponential increase in the distribution of the infringing 3-D CAD files throughout the Internet. ${ }^{53}$ This type of collateral effect would make it even more difficult to track, find, and takedown the websites hosting the infringing 3-D CAD files.

\section{A. Enforcing Patent Rights Under a Theory of Active Inducement Will} Likely Have a Minimal Effect, Only Finding the Most Defiant Websites Actively Inducing Patent Infringement

One potential route that may be pursued to assert patent rights is pursuing $\mathrm{CAD}$ file hosting websites, such as The Pirate Bay or DEFCAD, for actively inducing infringement, per 35 U.S.C. Section 271(b). ${ }^{54}$ Section 271(b) states, "[w] hoever actively induces infringement of a patent shall be liable as an infringer." 55 To be found committing "active inducement," the CAD file hosting websites would have to encourage downloaders to engage in infringing activity with "knowledge that the induced acts constitute patent infringement." 56

The seminal Supreme Court case on the dangers posed to intellectual property rights by file hosting websites was Metro-GoldwynMayer Studios Inc. v. Grokster, Ltd. ${ }^{57}$ In Grokster, the Supreme Court

52. Brean, supra note 45 , at 804 .

53. See T.C., What is the Streisand Effect?, THE ECONOMIST (Apr. 15, 2013), http:/www.economist.com/blogs/economist-explains/2013/04/economist-explains-what-

streisand-effect (describing "how efforts to suppress a juicy piece of online information can backfire and end up making things worse for the would-be censor"); see also Doherty, supra note 14, at 363 (describing the potential of the "Streisand Effect" in response to an attempt to suppress information).

54. See 35 U.S.C. $\S 271(b)(2006)$.

55. Id.

56. Global-Tech Appliances, Inc. v. SEB S.A., 131 S. Ct. 2060, 2065, 2068 (2011); see Metro-Goldwyn-Mayer Studios Inc. v. Grokster, Ltd., 545 U.S. 913, 938 (2005) (describing knowledge of copyright infringement where file hosting networks helped users find copyrighted material on their network); Brean, supra note 45 , at 794 .

57. See generally Grokster, 545 U.S. 913. 
dealt with defendant software companies utilizing peer-to-peer networks that were prominently employed in sharing copyrighted music and video files.58 Although the Grokster Court dealt with induced copyright infringement, the analysis for induced patent infringement parallels the analysis by the Court in Grokster. The Court found that file hosting networks' "unlawful objective is unmistakable" 59 where the networks "communicated a clear message by responding affirmatively to [user] requests for help in locating and playing copyrighted materials"60 but failed to "develop filtering tools or other mechanisms to diminish the infringing activity using their software." 61 The Court gave credence to the fact that secondary liability may be the best route to pursue for intellectual property owners, as "it may be impossible to enforce rights in the protected work effectively against all direct infringers, so that the only practical alternative is to go against the device's distributor for secondary liability on a theory of contributory ... infringement."62

The Supreme Court recently dealt with this theory of indirect patent infringement in Global-Tech Appliances, Inc. U. SEB S.A. In GlobalTech Appliances, Inc., the defendant company's subsidiary built and sold to Sunbeam Products, Inc., an exact copy-with the exception of cosmetic features-of a competing company's patented deep fryer, made by SEB S. A. 63 The Court set an elevated standard of "willful blindness," a "limited scope that surpasses recklessness and negligence" to find the requisite "knowledge that the induced acts constitute patent infringement." 64

In that case, the Court reiterated that willful blindness consists of two requirements: "(1) the defendant must subjectively believe that there is a high probability that a fact exists and (2) the defendant must take deliberate actions to avoid learning of that fact."65 The Court found evidence of actively induced infringement where the infringer knew of the patentee's superior product, and copied "all but the cosmetic features"; therefore, the defendant infringer "willfully blinded itself" to the fact that the patentee's product may be patented. ${ }^{66}$

Applying the Court's findings in Grokster and Global-Tech Appliances, Inc. to websites hosting CAD files, it seems possible that

58. See id. at 920 .

59. Id. at 940 .

60. Id. at 938 .

61. Id. at 939 .

62. Id. at 914 .

63. Global-Tech Appliances, Inc. v. SEB S.A., 131 S. Ct. 2060, 2064 (2011).

64. Id. at 2068-71 (describing the knowledge requirement needed to meet induced infringement per 35 U.S.C. § 271(b) (2006)).

65. Id. at 2070 .

66. Id. at $2071-72$. 
potential defiant hosting websites, such as The Pirate Bay and DEFCAD, may be found to have actively induced patent infringement under section 271(b). ${ }^{67}$ These types of websites seem to meet the minimal scienter requirement of "willful blindness," especially if they host 3-D CAD files that are digital copies of patented objects ${ }^{68}$ with titles, descriptions, or references to patented objects, and the website does nothing to prevent or filter such files. ${ }^{69}$ Also, since the defiant websites' intentions in hosting $\mathrm{CAD}$ files would be for the purpose of downloaders to print them-which would subsequently yield direct infringement under section 271(a) ${ }^{70}$-it seems possible that these defiant websites could be found actively inducing patent infringement under section $271(b) .{ }^{71}$

\section{B. The Improbability of Enforcing Patent Rights by Pursuing CAD File Hosting Websites Under a Theory That 3-D CAD Files Are "Components"}

Another potential avenue that patentees may be tempted to pursue against websites hosting 3-D CAD files is that of indirect infringement under section 271(c). Under section 271(c), indirect patent infringement occurs where someone "offers to sell ... or imports . . . a component of a patented machine ... or a material or apparatus ... constituting a material part of the invention ...."72

The Supreme Court discussed the treatment of source code and blueprints in Microsoft Corp. v. AT\&T Corp., where AT\&T brought suit against Microsoft due to Microsoft's utilization of "software code that . . . enables a computer to process speech in the manner" of AT\&T's patent. ${ }^{73}$ The Court discussed how software containing source code "might be compared to a blueprint (or anything containing design information, e.g., a schematic, template, or prototype)."74 Ultimately, the Court found the software containing the source code was not a

67. See THE PIRATE BAY, supra note 42 (describing one of the most notorious illegal file sharing websites' intention in sharing CAD files for use with 3-D printers and scanners).

68. See, e.g., Apple iPhone $53 D$ Model, 3D CAD BRowsER (Jan. 9, 2013), http://www.3dcadbrowser.com/download.aspx?3dmodel=61785 (displaying an example of a known, branded product's downloadable 3D CAD file).

69. See Metro-Goldwyn-Mayer Studios Inc. v. Grokster, Ltd., 545 U.S. 913, 939 (2005) (describing how the lack of filtering can give rise to the objective of induced infringement).

70. See 35 U.S.C. $\S 271$ (a) (2006) (defining direct patent infringement as being committed by "whoever without authority makes, uses, offers to sell, or sells any patented invention").

71. See Brean, supra note 45 , at $795-96$.

72. 35 U.S.C. $§ 271$ (c) (2006).

73. Microsoft Corp. v. AT\&T Corp., 550 U.S. 437, 441-42 (2007).

74. Id. at $449-450$. 
component, as "[a] blueprint may contain precise instructions for the construction and combination of the components of a patented device, but it is not itself a combinable component of that device."75 Although Microsoft dealt with a component in the context of section 271(f), there is no reason as to why "component" cannot be identically construed when looking at section 271 (c), ${ }^{76}$ since the term's context is analogous regarding the requirement of being sold or supplied in order to realize infringement. ${ }^{77}$

In light of Microsoft, the recent case of Ormco Corp. v. Align Technology, Inc. can be seen as creating uncertainty and confusion but at the same time offering potential hope to patentees, as it pertains to files being classified as components. ${ }^{78}$ In Ormco Corp, a district court used Microsoft's definition of a component and found an Amiga Disk File (ADF) was a component of patent claims. ${ }^{79}$ The court found

[a] data file like the ADF file does not merely instruct. . . how to act in a manner that infringes on [a] patented claim[. . . . [r]ather, it is information that is incorporated into other steps of the patented claims, without which the patented claim cannot fully be completed. 80

The court found the ADF file "[u]nlike a blueprint or 'template" and "more like an 'ingredient' in a recipe than the recipe card itself." 81

75. Id.

76. See Brean, supra note 45 , at 799 (describing how the term "component" should be construed equally between $\S 271$ (f) and $\S 271(\mathrm{c})$ ).

77. Compare 35 U.S.C. $\$ 271(c)$ (2006) ("Whoever offers to sell or sells within the United States or imports into the United States a component of a patented machine, manufacture, combination or composition, or a material or apparatus for use in practicing a patented process, constituting a material part of the invention, knowing the same to be especially made or especially adapted for use in an infringement of such patent, and not a staple article or commodity of commerce suitable for substantial noninfringing use, shall be liable as a contributory infringer."), with 35 U.S.C. $\S 271(f)$ (2006) ("Whoever without authority supplies or causes to be supplied in or from the United States all or a substantial portion of the components of a patented invention, where such components are uncombined in whole or in part, in such manner as to actively induce the combination of such components outside of the United States in a manner that would infringe the patent if such combination occurred within the United States, shall be liable as an infringer.").

78. Ormco Corp. v. Align Tech., Inc., 609 F. Supp. 2d 1057 (C.D. Cal. 2009).

79. See id. at 1071-72 (finding the 3-D data file used for the Invisalign $®$ system was a "component" under $\S 271(f)$ ).

80. Id. at 1071 .

81. Id. 
Although the Ormco Corp. case is not binding outside of the central district of California, its holding may be influential. Moreover, the district court in Ormco Corp. should have ruled a bit more narrowly when construing files to be components in the context of patent infringement. There are multiple file types with varying uses, and the specific ADF file referred to in the case was a proprietary file format "only readable by [the patentee's] proprietary software," which is a portion of an overarching, patented method of creating and manufacturing Invisalign retainers. ${ }^{82}$

When looking to Microsoft and Ormco Corp., obviously, the Supreme Court's classification of a component in Microsoft takes precedence. When construing the Court's determination of excluding from the classification of a component, a blueprint "or anything containing design information, e.g., a schematic, template, or prototype," a 3-D CAD file will likely be considered analogous to a blueprint or schematic rendering rather than a component under section 271 (c). ${ }^{83}$ This likely outcome will negate any potential for successfully asserting patent rights and bringing an indirect infringement suit under section 271(c) against websites hosting $\mathrm{CAD}$ files, even if the physical rendering of the 3.D CAD file is a direct infringement of a patented object.

\section{THE PROPOSITION OF A COLLABORATIVE, INTERGOVERNMENTAL DATABASE UTILIZING CAD FILE-RECOGNITION SOFTWARE}

Finding an effective balance that fosters the continued growth and innovation of the 3-D printing industry for the betterment of society while simultaneously preventing patent infringement by DIY users of 3$D$ printing will likely be very difficult. ${ }^{84}$ The potential use of the World Intellectual Property Organization's (WIPO) intergovernmental network

82. Id. at 1062; see also Yangaroo Inc. v. Destiny Media Techs. Inc., 720 F. Supp. 2d 1034 (E.D. Wis. 2010) (distinguishing Ormco as claiming a patent over a method of creating or manufacturing content).

83. Microsoft Corp. v. AT\&T Corp., 550 U.S. 437, 450 (2007). See generally Lucas S. Osborn, Regulating Three-Dimensional Printing: The Converging Worlds of Bits and Atoms, 51 SAN DIEGo L. REV. 553, 587 (2014) ("If a court analogizes a CAD file to a blueprint it would probably not infringe ....").

84. See generally Brean, supra note 45 , at 804 (describing the difficulties with the current state of patent law and preventing patent infringement while encouraging innovation in 3-D printing); Finocchiaro, supra note 41, at 507-08 (suggesting that policymakers and judges limit regulatory intrusions into 3-D printing); WEINBERG, supra note 6, at 2 (suggesting how "incumbants [may] try to cripple 3D printing with restrictive intellectual property laws."). Cf. Yoches, supra note 14 (mentioning the possibility of a "centralized database of patented designs"). 
similar to that of Interpol's "I-24/7" network85 combined with the implementation of 3-D CAD file recognition software similar to software used for 3-D facial recognition, could be used for prerequisite crossreferencing, thus confronting the foreseeably large problem of the DIY user. ${ }^{86}$ This prerequisite cross-referencing would act as a prophylactic means of enforcing patent rights by fending off any attempted direct infringement under section 271(a), thereby preventing anyone from rising to the level of making, using, offering to sell, or selling any patented invention without authority. ${ }^{87}$ Although beyond the scope of this Note, it also may be possible that, at least in the United States, legislation will pass requiring 3-D printer manufacturers to install some type of "fail safe" for cross-referencing this proposed WIPO database prior to printing. 88

\section{A. WIPO's Current Intergovernmental Network, Similar to Interpol's I- 24/7 Network, Will Ensure the Centralized Management of CAD File Renderings for Patents Among Member Countries}

WIPO is an agency of the United Nations that aims to "lead the development of a balanced and effective international intellectual property system that enables innovation and creativity for the benefit of all."89 WIPO currently fosters patent protection in 148 countries that have signed onto the Patent Cooperation Treaty (PCT), "mak[ing] it possible to seek patent protection for an invention simultaneously in each of [the member] countries by filing a single 'international' patent application instead of filing several separate national or regional patent

85. See Todd Sandler, An Evaluation of Interpol's Cooperative-Based Counterterrorism Linkages, 54 J.L. \& ECON. 79, 82-83 (Feb. 2011) (describing INTERPOL's I-24/7 as a "secure global communication system").

86. See Kevin Bonsor \& Ryan Johnson, How Facial Recognition Systems Work, HowSTUFFWORKS, http://electronics.howstuffworks.com/gadgets/high-tech-gadgets/facialrecognition.htm (last visited Dec. 2, 2013) (describing how facial recognition software detects, measures, and matches 3-D facial images).

87. See 35 U.S.C. $\$ 271$ (a) (2006) (defining direct patent infringement as: "[W]hoever without authority makes, uses, offers to sell, or sells any patented invention, within the United States or imports into the United States any patented invention during the term of the patent therefor, infringes the patent.").

88. See generally Wickard v. Filburn, 317 U.S. 111, 125 (1942) (describing Congress' ability to reach local activity under the interstate commerce clause due to an activity's aggregate effect). Cf. H.R. 1474, 113th Cong. (2013) (displaying congressional reaction to 3-D printing by unsuccessfully attempting to extend the Undetectable Firearms Act of 1988 to cover undetectable firearm receivers and magazines).

89. Inside WIPO, WORLD INTELL. PROP. ORG., http://www.wipo.int/about-wipo/en/ (last visited Nov. 22, 2013). 
applications."90 Given that WIPO is the most central means of international patent protection and enforcement, it seems appropriate that the addition and implementation of an intergovernmental 3-D CAD file database would occur within WIPO's network.

Similar in size and collaborative function to that of the WIPO, at least in regard to collaborative enforcement of respective rights, the International Criminal Police Organization (Interpol) was created to "enable police around the world to work together to make the world a safer place." 91 Interpol does not fulfill the function of arresting criminals but instead facilitates the arrest of criminals by using Interpol's vast array of resources, one of which is Interpol's I-24/7 network. ${ }^{92}$ Although Interpol's focus is on criminal activity, the intergovernmental organization's I-24/7 network can stand as an example of a vast and highly effective information network that is focused on allowing a "secure global . . . support network that connects all 190 [member countries] ... allowing them to instantly access, request and submit vital data."93

Economic analysis on an international, proactive approach to terrorism, such as Interpol's increased effort since 9/11, found that it would "provide positive externalities to all at-risk countries[,]" thus yielding "a pure public good to all potential target countries." 94 The failure of member states to internalize the positive externalities gained from a proactive approach results in criminals reaping the benefit. ${ }^{95}$ Additionally, Sandler's economic analysis shows that Interpol's cooperative and proactive measures to fighting crime are exceptionally cheaper than defensive or military action. ${ }^{96}$ This type of economic analysis shows that there is a "clear role for an international

90. PCT FAQs: Protecting your Inventions Abroad: Frequently Asked Questions About the Patent Cooperation Treaty, WORLD INTELL. PROP. ORG. (July 2014), http://www.wipo.int/ pct/en/faqs/faqs.html.

91. Compare World Intellectual PCT - The International Patent System, WoRLD INTELL. PROP. ORG., http://www.wipo.int/pct/en/ (last visited Nov. 22, 2013) (explaining WIPO consists of 148 member countries honoring international patents), with Overview, INTERPOL, http:/www.interpol.int/About-INTERPOL/Overview (last visited Nov. 22, 2013) (explaining INTERPOL consists of 190 member countries).

92. See Sandler, supra note 85 , at 82 .

93. Priorities, INTERPOL, http://www.interpol.int/About-INTERPOL/Priorities; see also Sandler, supra note 85 , at 83 (describing Interpol's I-24/7 database as "allow[ing] police forces to share their data," but also giving member countries access to the organizations growing data on terrorists).

94. Sandler, supra note 85 , at 85 .

95. Id.

96. See id. at 108 . 
institution, such as Interpol, to bolster these proactive measures" and collective actions to prevent crime among member nations. ${ }^{97}$

Although enforcing intellectual property law is vastly different than fighting international crimes such as terrorism or human trafficking, it does not take much to see the positive externalities gained from a proactive approach to preventing patent infringement on a global scale. This can especially be seen with the expected increase in usage of continually improving 3-D printing and scanning technology at cheaper prices and with the spread of 3-D CAD file sharing networks.

The Director General of WIPO, Francis Gurry, has stated, "[j]ust as participation in the physical economy requires access to roads, bridges, and vehicles to transport goods, similar infrastructure is needed in the virtual and knowledge economy."98 Gurry spoke to the inefficiency of having to search multiple countries' databases to see if one's intellectual property is protected in each country, and argued that there should be one centralized global portal for such inquiries. ${ }^{99}$ The ability for WIPO to integrate a 3-D CAD file database into its intergovernmental network, along with 3-D CAD file recognition software, will provide the means for efficient, accurate, and trusted global patent searches at the click of a button, as well as the ability to prevent DIY users from 3-D printing infringing objects. The same type of benefits realized from Interpol's proactive approach to fighting crime can be achieved through WIPO's integration of a 3-D CAD file database with recognition software, enabling requisite cross-referencing by member nations, thus drastically weakening the ability of individuals to infringe patents through 3-D printing. ${ }^{100}$

B. The WIPO's Current Patent System Could Be Altered to Realize the Benefits of a 3-D CAD File Database and File Recognition Software That Analyzes and Validates Files Against WIPO's File Database as a Prerequisite to 3-D Printing

WIPO and most countries' intellectual property offices require illustrations ${ }^{101}$ of one's invention when filing for patents. ${ }^{102}$

97. Id. at 85 .

98. An Interview with WIPO Director General Francis Gurry, WIPO MAG. (Sept. 2010), http://www.wipo.int/wipo_magazine/en/2010/05/article_0001.html.

99. Id.

100. See Sandler, supra note 85 , at 85 (speaking to the positive externalities realized by member nations of Interpol through the IGO's proactive approach to fighting terrorism).

101. See Regulations Under the PCT: Rule 11, WORLD INTELL. PROP. ORG., http://www.wipo.int/pct/en/texts/rules/r11.htm (last visited Oct. 30, 2014). 
"Applications for patents rely fully on the drawings." 103 Most countries require multiple views of the invention in the patent application. ${ }^{104}$ These illustrations are to be drawn or printed as black-and-white line art. ${ }^{105}$ Further, if the patent applicant is not satisfied with the adequacy of a black-and-white drawing, the applicant usually may submit photographs instead, depicting only one side of the invention per photograph. ${ }^{106}$ Such limited views render the task of depicting specific, accurate, and holistic representation of one's invention very challenging. ${ }^{107}$

3-D CAD files offer the ability to provide greater accuracy and detail to illustrations in patent applications than the 2-D illustrations currently required by WIPO and other member countries' patent offices. Inventors frequently consult with patent drafting companies to create 3D CAD files of their inventions. 108 Inventors find drafting their inventions in 3-D CAD files helpful, ${ }^{109}$ yielding the ability to kill two birds with one stone, as the 3-D CAD files provide inventors with patent drawings that comply with U.S. Patent and Trademark Office (USPTO) and PCT requirements while also providing inventors with a 3-D CAD file for manufacturing and attracting investors and licensees. ${ }^{110}$ Additionally, CAD programs provide the ability to change one's illustration with minimal effort. Through utilizing 3-D CAD files in patent applications, as well as storing and sharing these illustrations worldwide through its global network, WIPO would certainly be pursuing its goal of "building, and expanding access to, technology databases, and the modernization of national IP offices."111 The ability to rotate and view the $3-\mathrm{D}$ rendering of an invention in a patent

102. See Bernadette Marshall, Better Drawings Make a Better Patent, WIPO Mag. (Apr. 2010), http://www.wipo.int/wipo_magazine/en/2010/02/article_0008.html (describing how the USPTO and multiple countries require drawings when filing patents).

103. Id.

104. See id.

105. See id.

106. See id.

107. See id.

108. See generally Amar Sehmi, The Importance of Patent Drawings and $3 D$ Models, INVENTIA PATENT DRAFTING (Aug. 28, 2013), http://inventiapatent.com/2013/08/28/theimportance-of-design-patent-drawings-and-3d-models/ (describing the usage of 3-D CAD file renderings for patent applications and manufacturing).

109. See id. (describing the utility gained from 3-D CAD files in patent applications and manufacturing).

110. See Gene Quinn, Patent Illustrations and Invention Drawings, What Do You Need?, IPWATCHDOG (Sept. 10, 2011, 6:41 PM), http://www.ipwatchdog.com/2011/09/10/patentillustrations-and-invention-drawings-what-do-you-need/id=19077/ (describing the attractiventess of 3-D CAD renderings to investors and licensees).

111. See An Interview with WIPO Director General Francis Gurry, supra note 98. 
application from any desired angle would be unprecedented. This type of illustration can truly help patent processors determine if a design is patentable.

The existence of 3-D CAD file illustrations of inventions would enable WIPO to store the 3-D CAD files of inventions that are granted patents. WIPO could then utilize its PATENTSCOPE database to make the 3-D CAD files available for viewing purposes to both inventors and patent processors. ${ }^{112}$ Additionally, assuming appropriate software is available, the integration of 3-D CAD file recognition software within WIPO's network could allow for the streamlined evaluation of patent applications, as patent processors could simply upload and cross reference the 3-D CAD file in the recognition software program.

The dominant benefit of 3-D CAD file illustrations is that they would be stored within WIPO's network and used for prerequisite crossreferencing from 3-D printers prior to printing. Although this sounds extremely ambitious or even fanciful, 3-D CAD file recognition software is not particularly far-fetched. The software would work in an analogous fashion to 3-D facial recognition, which has displayed up to 99 percent accuracy. ${ }^{113}$ The software would analyze the 3-D CAD file in similar fashion to printing 3-D objects: layer by layer. ${ }^{114}$ The angles and shape of the figure would produce code, which then could be cross-referenced against WIPO's 3-D CAD file database, containing all patented objects' 3-D CAD file illustrations and their respective codes. ${ }^{115}$ This would function as an overlay of the digital representations. If the recognition software recognized a match within a certain deviation of the patented object, WIPO's database would send code back to the 3-D printer informing it of the match, thus preventing the 3-D printer from printing the object.

112. See PATENTSCOPE, WORLD INTELl. PROP. ORG., http://patentscope.wipo.int/ search/en/search.jsf (last visited Dec. 2, 2013).

113. See Jeremy Hsu, How Face Recognition Tech Will Change Everything, DIscoverY NEwS (June 11, 2013, 11:25 AM), space http://news.discovery.com/tech/biotechnology/how face-rec-tech-change-everything-130611.htm (describing the accuracy and future potential of facial recognition software).

114. See Bonsor \& Johnson, supra note 86 .

115. See id. 


\section{The Integration of a 3-D CAD File Database with 3-D CAD File Recognition Software, Requiring Cross-Referencing Prior to Printing, Would Serve as a Viable Enforcement Mechanism, at Least for Blatant Patent Infringement in 3-D Printing}

This type of intergovernmental program, combined with the effort and cooperation of WIPO member countries, would serve as an expedited enforcement mechanism, at least for patents and the feared potential of unlimited, blatant patent infringement-thanks to improving and spreading 3-D printing technology and 3-D CAD file hosting networks. Currently, WIPO leaves to the patentee and his or her attorney the task of enforcing a design patent registered through WIPO in multiple member countries. ${ }^{116}$ Patentees, large and small, have to exert time and effort in finding a patent attorney and "arrang[ing] for a writ or complaint to be served to the alleged infringer." 117 The patentee can also request an injunction preventing the alleged infringer from continuing the infringing activity. ${ }^{118}$ Assuming the case is not settled out of court, the patentee exerts additional time and effort in attempting to enforce his or her rights by having the court determine if the patent was infringed. 119

With respect to the jurisdiction of the United States, the United States Supreme Court finds patent infringement:

if, in the eye of an ordinary observer, giving such attention as a purchaser usually gives, two designs are substantially the same, if the resemblance is such as to deceive such an observer, inducing him to purchase one supposing it to be the other, the first one patented is infringed by the other. ${ }^{120}$

When looking to determine if an object has infringed a patent, the Court looks to the illustration in the patent, as "a design is better represented by an illustration 'than it could be by any description and a description

116. See World Intell. Prop. ORG., WiPo Intellectual Property Handbook: POLICY, LAW AND USE 207 (2004), available at http://www.wipo.int/export/sites/www/ about-ip/en/iprm/pdf/ch4.pdf.

117. Id. at 210 .

118. See id.

119. Id.

120. Gorham Co. v. White, 81 U.S. 511, 628 (1871); see also Egyptian Goddess, Inc. v. Swisa, Inc., 543 F.3d 665, 678 (Fed. Cir. 2008) (describing the sole test for determining whether a design infringes a patent as the "ordinary observer" test articulated by the Supreme Court in Gorham). 
would probably not be intelligible without the illustration."'121 Applying this to the DIY user who creates or replicates the patented item depicted in a patent illustration-whether knowingly or unknowinglyit is obvious that he or she would clearly be committing patent infringement. ${ }^{122}$

Seeing that courts look to the illustration in the patent and compare it with the allegedly infringing object, this proposed requisite crossreferencing of 3-D CAD file illustrations via 3-D CAD file recognition software-prior to a 3-D printer allowing a user to print-can be seen as serving the role of the "ordinary observer."123 At the very least, this requisite step through WIPO's global network and database could serve the expedient function of preventing the foreseeably widespread, blatant, and unlawful replication of patented objects by DIY users in 3D printing. ${ }^{124}$

This type of system would benefit inventors, member countries' patent offices, and patentees. Inventors and patentees could have the comfort of knowing their inventions would truly be protected from infringement via 3-D printing. An automated system that can help prevent the blatant infringement of patent rights has the long-run potential to decrease operating costs within WIPO and member countries' patent offices while simultaneously helping to expedite the processing of patent applications. The global realization of such a collaborative and proactive program would produce an increase in positive externalities to multiple countries' industries that may be at risk of patent infringement by DIY users of 3-D printing technology. ${ }^{125}$ Most importantly, this type of program could help find the seemingly impossible balance of calming worries over patent infringement in 3-D printing while fostering and allowing growth in the 3-D printing industry.

121. See 543 F.3d at 679 (citing Dobson v. Dornan, 118 U.S. 10, 14 (1886)).

122. See generally Michael, supra note 14 (describing how the building of a patented product yourself is patent infringement).

123. See 81 U.S. at 628 (referring to the ordinary user test); $543 \mathrm{~F}$.3d at 678 (referring to the comparison of an allegedly infringing object to the illustration in the patent).

124. See 35 U.S.C. $\$ 271$ (a) (2006) (referring to the production of a patented object as infringement).

125. See Sandler, supra note 85 , at 85 (speaking to positive externalities realized by member nations of INTERPOL thanks to taking a proactive approach to fighting terrorism after $9 / 11$ ). 
D. When Weighing the Costs and Collaborative Efforts Needed to Implement a 3-D CAD File Database and 3-D CAD Recognition Software Within WIPO, the Potential of Such a System Becomes Uncertain

Although it is easy to solely contemplate the potential benefits of such a proactive and collaborative program to prevent patent infringement in 3-D printing, one must also consider the costs and issues associated with this proposed program. When these costs and issues are taken into account, the uncertainty in achieving such a program becomes apparent. The potential start-up costs, the legislation needed in each country to take advantage of such a program, and the lack of 3-D CAD file recognition software all serve as hurdles that may deter and hinder this type of program from being implemented.

First, the start-up costs involved with this type of program would be fairly expensive. With at least eighty-one different CAD file types and each type varying in size and format, creating a WIPO database that accepts multiple file types, dependent on different industry applications, seems like a tedious and expensive task. ${ }^{126}$ The 3-D CAD files that would be collected within WIPO's 3-D CAD file database would likely take up more storage ${ }^{127}$ than the typical patents and two-dimensional illustrations currently in WIPO's PATENTSCOPE database. ${ }^{128}$ Increased server space will likely be needed by WIPO to accommodate the new 3-D CAD files, even including applications for review. With the "[f]astest growth in [patents in] the past [eighteen] years" at 2.35 million applications filed worldwide, it is easy to see how much server space these 3-D CAD files would occupy. ${ }^{129}$ Furthermore, the respective evaluation process and the costs of having to train patent processors at WIPO to gain experience with $3-\mathrm{D}$ CAD files would likely be cumbersome and costly. Even with an annual income of over 300 million Swiss Francs, a program of this scale seems difficult to justify unless there is significant member buy-in and support. ${ }^{130}$

126. See List of File Formats: Computer-aided Design (CAD), WIKIPEDIA, http://en.wikipedia.org/wiki/List_of_file_formats\#Computer-aided (last visited Dec. 2, 2013) (listing and briefly describing eighty-one different CAD file formats).

127. See generally Understanding File Sizes, GREENNET, http://www.gn.apc.org/support/ understanding-file-sizes (last visited Dec. 2, 2013).

128. See PATENTSCOPE, supra note 112 (referring to WIPO's current patent database).

129. See World Intellectual Property Indicators 2013, WORLD INTELL. PROP. ORG., http://www.wipo.int/export/sites/www/pressroom/en/documents/wipi_2013_infographic1.pd f (last visited Dec. 2, 2013).

130. See Frequently Asked Questions About WIPO: How is WIPO Funded?, WoRLD INTELL. PROP. ORG., http://www.wipo.int/about-wipo/en/faq.html (last visited Dec. 2, 2013). 
Second, the legislative cooperation and collaborative effort needed among member countries would likely act as a deterrent to a WIPO 3-D CAD file program. Although beyond the scope of this Note, it seems possible that legislation requiring 3-D printers to cross-reference this 3D CAD file program may find traction in the United States, possibly through routes such as the interstate commerce clause. ${ }^{131}$ With improving technology in 3-D printing and scanning, it seems possible that the potential aggregate effect of DIY users infringing on patents through the unlawful $3-D$ printing of patented objects could have a drastic effect on interstate commerce, especially in the form of excessive lost profits. ${ }^{132}$ Although such legislative cooperation may be found in the United States, such cooperation among other countries is unknown. WIPO Director General Francis Gurry echoes this point in stating, "Norm-making is generally the most difficult area in which to achieve multilateral agreement."133 Asymmetries in WIPO member countries' resources, information, and networking capabilities are also hurdles to cooperation. ${ }^{134}$ Further, even though WIPO member nations may favor such a program to prevent patent infringement in 3-D printing, a stalemate of sorts may occur. WIPO may not implement the proposed 3$\mathrm{D}$ CAD file database and recognition program without first having legislative support and confirmation from member countries; while at the same time, member countries may not pass legislation requiring $3-\mathrm{D}$ printers to cross-reference such a program without WIPO first implementing the program.

The combination of a nonexistent market for 3-D CAD file recognition software with the unknown effectiveness of such software may serve as a deterrent to WIPO undertaking such an ambitious program. Unless patent offices around the world begin allowing 3-D CAD files to substitute as drawings or illustrations in patent applications, it seems there is no market or incentive for producing this type of software. Further, 3-D printing is still in its nascent stages. ${ }^{135}$ " $[\mathrm{H}]$ ome $3-\mathrm{D}$ printing 'remains a hobbyist-driven enterprise with a high barrier to entry." 136 Even if there were a market for such software, the ability of the software to accurately recognize whether a 3-D CAD file would infringe a patent's 3-D CAD file would, at best, be uncertain. The

131. See U.S. ConST. art. I, § 8, cl. 3 ("To regulate Commerce with Foreign Nations, and among the several States, and with the Indian Tribes ....").

132. See generally Wickard v. Filburn, 317 U.S. 111, 125 (1942) (describing Congress' ability to reach local activity under the interstate commerce clause and the aggregate effect of a particular action).

133. An Interview with WIPO Director General Francis Gurry, supra note 98.

134. Id.

135. See Finocchiaro, supra note 41 , at 489.

136. Id. (citing Hanna, supra note 15). 
software would have to undergo rigorous testing to fine-tune its accuracy, as the global trust of patentees would ride on such a program preventing patent infringement in various $3-\mathrm{D}$ printing applications.

\section{CONCLUSION}

Considering the current functions served by 3-D printing, and the forecasted potential and applications of such technology, it is important to foster a balance of allowing the 3-D printing industry to prosper while promoting and enforcing patent rights. With base estimates predicting the 3-D printing capital goods industry to grow at an annual growth rate of 20 percent to $\$ 9$ billion by 2020 , and bull market estimates growing at an annual growth rate of 34 percent to $\$ 21$ billion dollars by 2020 , it becomes apparent that a balanced solution to preventing any patent infringement that may accompany this growth should be found sooner rather than later. ${ }^{137}$

Seeing that the current state of patent law does little to protect patentees against the foreseeable problem of DIY users with cheaper and improving 3-D printing technology, it is clear that the potential patent infringement issues accompanying such change in technology should remain on patent attorneys', legislators', and patentees' radars. Although the optimal solution to this potential problem has yet to be found, a proactive and collaborative approach may yield positive externalities to all countries at risk of patent infringement, and thus decrease the benefit to potential patent infringers. A database that stores 3-D CAD file renderings of patents in lieu of the current twodimensional illustrations, along with the requisite cross-referencing of this database while utilizing 3-D CAD file recognition software prior to printing any object, serves as one of the few proposed solutions that could truly find a balance between fostering growth in 3-D printing and protecting and enforcing patent rights.

Although this proposed solution raises uncertainties surrounding start-up capital, WIPO member countries' adoption and cooperation, and the feasibility of 3-D CAD file recognition software, at the very least, this proposed solution adds to the ever-amplifying conversation regarding preventing IP infringement in 3-D printing. More importantly, this suggested solution is one of the few proposed solutions

137. See MORGAN STANLEY RESEARCH, supra note 9, at 20, 24 (describing the estimated annual growth rate and estimated market through 2020 for capital goods in the 3-D printing industry). 
that respects IP rights while simultaneously allowing 3-D printing to flourish. 138

138. See Brean, supra 45 note at 789 (describing pursuing distributors of $3-\mathrm{D}$ CAD files under a theory of indirect infringement); Doherty, supra note 14, at 364-70 (proposing a "Digital Millennium Patent Act," reminiscent of the "Digital Millennium Copyright Act"). 